\title{
Comparative Evaluation of Dentifrice Containing Herbal Extract With Triclosan/Polymer Containing PVM/MA in Its Ability To Control Plaque and Gingival Inflammation
}

\author{
Dr Ketaki Upadhye ${ }^{1,}$ Dr Rizwan M. Sanadi ${ }^{2}$ Dr Pradeep Chitnis ${ }^{3}$ \\ ${ }^{I}$ MDS (Periodontics) Department Of Periodontics , Dr G.D. Pol Foundation, YMT Dental College And \\ Hospital, Institutional Area, Sector 4, Kharghar, Navi Mumbai, India \\ ${ }^{2}$ Professor \& Guide Department Of Periodontics , Dr G.D. Pol Foundation, YMT Dental College And Hospital,, \\ Institutional Area, Sector 4, Kharghar, Navi Mumbai, India \\ ${ }^{3}$ MDS Periodontics Manusmriti Apartments, Daulat Nagar, Santacruz (West), Mumbai
}

\begin{abstract}
:
Aim: To comparatively evaluate the dentifrice containing herbal agents and Triclosan/polymer containing PVM/MA in its ability to control Plaque and Gingival inflammation

Materials and Methods: Subjects for the study were selected from the outpatient department of Periodontics from a Dental College, Navi Mumbai, India. 60 subjects with established dental plaque and gingivitis were randomly assigned to either Triclosan or Herbal dentifrice group in a randomized controlled crossover clinical trial. The plaque index, sulcus bleeding index and gingival index scores at baseline and 3 weeks were assessed. Statistical analysis was performed using Paired $\mathrm{t}$-test and Unpaired $\mathrm{t}$-test. A $p$ value of 0.05 was considered for statistical significance.

Results: On intragroup comparison, there was a statistically significant reduction $(p<0.001)$ in plaque index, sulcus bleeding index and gingival index scores in both groups at 3 weeks compared with the baseline. Intergroup comparison was statistically significant in favour of the Triclosan group as opposed to the Herbal group. No adverse events were reported and both the dentifrices were well-tolerated.

Conclusion: Triclosan/polymer with PVM/MA containing dentifrice was more effective than the herbal based dentifrice in reducing plaque and gingival inflammation.
\end{abstract}

Keywords: Triclosan, Herbal, dentifrices, gingivitis, plaque reduction, crossover

\section{Introduction}

The relationship between dental plaque and gingival and periodontal disease has been extensively studied and established. Epidemiological studies revealed a peculiarly high correlation between supragingival plaque levels and chronic gingivitis ${ }^{1}$. Clinical research led to the proof that plaque was the primary etiological factor in gingival inflammation. The products of biofilm bacteria are known to initiate a chain of reactions leading to host protection but also tissue destruction.

The concept of the primary prevention of gingivitis derives from the assumption that gingivitis is the precursor of periodontitis and that maintenance of a healthy gingiva will prevent periodontitis. The mainstay of primary and secondary prevention of periodontal diseases is the control of supragingival plaque ${ }^{2,3}$. Plaque control plays a major role in prevention of gingivitis and periodontitis ${ }^{4}$. The Socransky group confirmed this finding and reported that a permanent optimal supragingival plaque control regimen can alter the composition of the pocket microbiota and lower the percentage of periodontopathic bacteria aiding in maintenance of gingival and periodontal health ${ }^{5}$.There is substantial evidence which shows that plaque and thereby gingivitis and periodontal diseases can be controlled most reliably through toothbrushing supported by other mechanical cleansing procedures. However a significant proportion of individuals fail to practise a high standard of removal of plaque thereby necessitating the introduction of appropriate chemical agents and herbal agents to aid in prevention of plaque and gingivitis. All these agents have been tried and tested in several clinical studies and have been found to be effective in plaque control.

The Following Agents Have Been Used Extensively For Effective Plaque Control And Reduction In Gingival Inflammation:

Phenols ${ }^{6}$ include a non-ionic antimicrobial agent eg: triclosan (2,4,4'-trichloro-2'-hydroxydiphenyl ether) with a wide spectrum of activity. It is bacteriostatic at low concentration and bacteriocidal at high concentration.Quaternary ammonium compounds ${ }^{6}$ namely Benzalconium chloride and Cetylpyridinium chloride (CPC) have been used in wide variety of antiseptic mouthrinse products. Bisbiguanide antiseptic ${ }^{6}$ include Chlorhexidine which is by far the most studied and effective antiseptic for plaque inhibition and the 
prevention of gingivitis. Polyvinylmethyl ether/ maleic acid (PVM/MA) Copolymer enhanced the activity of triclosan $(\mathbf{G a n t r e z})^{7}$ by increasing the retention of triclosan.

\section{Herbal Extracts Include The Following Agents:}

Punica granatum ${ }^{8}$ has been found to be particularly effective for controlling oral inflammation, as well as bacterial and fungal counts in periodontal disease.

Zanthoxylum armatum ${ }^{9}$ is used to cure toothache and other diseases of teeth. The plant possesses antioxidant, anti- inflammatory, antimicrobial and antifungal activities.

Acacia arabica ${ }^{10}$ is considered as an astringent and credited with the antimicrobial activity.

Triphala acts as anticaries agents strongly inhibits the sucrose or glucan induced aggregations of S. Mutans ${ }^{11}$ and strengthens the gums, prevents and treats several diseases of mouth such as dental caries, spongy and bleeding gums, gingivitis and stomatitis ${ }^{12}$. The strong antioxidant activity of Triphala may be partially responsible for many of the biological properties ${ }^{13}$.

Embelia ribes ${ }^{14}$ reportedly possesses antioxidant, anti-inflammatory and analgesic properties.

Vitex negundo ${ }^{15}$ has successfully demonstrated anti- microbial and anti-inflammatory activity through various experimental studies.

Salvadorapersica (Miswak) ${ }^{16}$ has been reported to have anti- microbial, anti-plaque, analgesic, antiinflammatory, and astringent activities.

Acacia farnesiana ${ }^{17}$ has astringent and anti inflammatory properties of which are beneficial in dental conditions such as gingivitis and dental caries.

Acacia catechu ${ }^{18}$ has been credited with properties such as antibacterial, anti- inflammatory, antioxidant and astringent, which may be useful in dental conditions like gingivitis and periodontitis.

Mimusops elengi ${ }^{19}$ possesses analgesic, anti-inflammatory, antimicrobial, antioxidant properties which are highly beneficial in oral conditions like gingival bleeding.

Trachyspermum ammi ${ }^{20}$ shows significant antimicrobial potential against all pathogens as well as analgesic activity which may be beneficial in oral conditions such as toothache.

Azadirachta indica (Neem) ${ }^{21}$ has been considered for its medicinal properties as well as an astringent, antiseptic, insecticidal, antiulcer agent for a long time have been used in the treatment of gingivitis and periodontitis.

Several studies have shown the benefits of one agent over the other. Hence the purpose of the present study was to compare and evaluate the plaque control and anti-gingivitis properties/ benefits of the conventional dentifrice and dentifrice containing herbal extracts.

\section{Selection of study participants}

\section{Materials And Methods}

Subjects for the study were selected from the outpatient department of Periodontics from a Dental College, Navi Mumbai, India. 60 subjects with established dental plaque and gingivitis were randomly assigned to either Triclosan or Herbal dentifrice group in a randomized controlled crossover clinical trial. Patients were informed about the study and written consent was obtained. The selection of the subjects was based on the following criteria.

\section{Inclusion Criteria}

Age Group of 18- 35 years

Clinical signs of gingivitis (bright red discolouration of gingiva, bleeding on probing, oedematous gingiva).

Probing depth of $<3 \mathrm{~mm}$ with no evidence of clinical attachment loss

Systemically healthy and co-operative subjects

\section{Exclusion Criteria}

History of any periodontal treatment in last 6 months

Subjects with history of usage of medications such as antibiotics and analgesics within past 6 weeks

Subjects with history of use of over the counter antioxidants like Vitamin C, Vitamin E or $\beta$ - Carotene within the past 3 months.

Smokers \& subjects using tobacco in any form

Pregnant \& lactating females \& those on oral contraceptive pills

\section{Materials}

The products used included Colgate Total® containing Triclosan was manufactured by ColgatePalmolive Ltd, India. Complete Care ${ }^{\circledR}$ containing multiple herbal extracts like Punica granatum, Embelia ribes, Zanthoxylum Armatum, Acacia Arabica, Terminalia Chebula, Terminalia Bellerica, Emblica 
Officinalis, Embelia Ribes, Azadirachta Indica, Vitex Negundo, Salvadora Persica, Acacia Farnesiana, Acacia Catechu, Mimosops Elengi was manufactured by Himalaya Drug Company, Bangalore, Indiaand a Bland dentifrice containing no specific antimicrobial agent. With the dentifrices, the subjects were also provided with a soft bristled toothbrush

\section{Study design}

The subjects received full mouth oral prophylaxis and were motivated and educated to perform Modified Bass brushing technique. They were asked to refrain from any other forms of oral hygiene practises during the study period. Following allocation in the Triclosan and Herbal group, the subjects were provided with the respective products and were asked to use them for a period of 3 weeks followed by a washout period of 2 weeks was given during which the subjects were instructed to use the bland dentifrice. This was followed by a crossover period of 3 weeks. Oral prophylaxis was carried out before (baseline) and after (3 weeks) both study period 1 and 2.

Following Clinical Parameters Were Recorded:

- $\quad$ Plaque Index (Silness \& Loe, 1964) ${ }^{22}$

- $\quad$ Sulcus Bleeding Index (Muhlemann \& Son, 1971) ${ }^{23}$

- $\quad$ Gingival Index (Loe \& Silness, 1963) ${ }^{22}$

\section{Statistical Analysis}

After the completion of the study, statistical analysis was carried out. The analysis were performed using SPSS software version 17. Descriptive statistics were expressed as mean \pm standard deviation (SD) for each group. The change in mean scores of various indices in each group before and after crossover was analyzed using Paired Student ' $t$ ' test. Intergroup comparison was done using Unpaired t test. In the above tests, $p$ value less than or equal to $0.05(\mathbf{p} \leq \mathbf{0 . 0 5})$ was taken to be statistically significant.

Intragroup comparison:

\section{Results}

Table no. 1: Intragroup comparison of Plaque Index in Herbal group before and after crossover

\begin{tabular}{|l|l|l|l|l|l|}
\hline & $\begin{array}{l}\text { Baseline } \\
\text { (mean } \pm \text { SD) }\end{array}$ & $\begin{array}{l}\text { Final } \\
\text { (mean } \\
\text { SD) }\end{array}$ & $\begin{array}{l}\text { Mean } \\
\text { Change }\end{array}$ & $\begin{array}{l}\text { \% } \\
\text { reduction }\end{array}$ & $\begin{array}{l}\text { P value } \\
\text { (Paired t } \\
\text { (est) }\end{array}$ \\
\hline \multicolumn{6}{|c|}{ Before crossover } \\
\hline $\begin{array}{l}\text { Plaque } \\
\text { index }\end{array}$ & $2.05 \pm 0.28$ & $0.86 \pm 0.23$ & $1.19 \pm 0.25$ & $58.05 \%$ & $<0.001^{*}$ \\
\hline \multicolumn{7}{|c|}{ After crossover } \\
\hline $\begin{array}{l}\text { Plaque } \\
\text { index }\end{array}$ & $1.45 \pm 0.27$ & $0.47 \pm 0.17$ & $0.98 \pm 0.28$ & $67.59 \%$ & $<0.001^{*}$ \\
\hline
\end{tabular}

Table no. 2: Intragroup comparison of Plaque Index in Triclosan group before and after crossover

\begin{tabular}{|l|l|l|l|l|l|}
\hline & $\begin{array}{l}\text { Baseline } \\
(\text { mean } \pm \text { SD })\end{array}$ & $\begin{array}{l}\text { Final } \\
\left(\begin{array}{l}\text { mean } \\
\text { SD) }\end{array}\right.\end{array}$ & $\begin{array}{l}\text { Mean } \\
\text { Change }\end{array}$ & $\begin{array}{l}\text { \% } \\
\text { reduction }\end{array}$ & $\begin{array}{l}\text { P value } \\
\text { (Paired t } \\
\text { test) }\end{array}$ \\
\hline \multicolumn{7}{|c|}{ Before crossover } \\
\hline $\begin{array}{l}\text { Plaque } \\
\text { index }\end{array}$ & $2.06 \pm 0.26$ & $0.56 \pm 0.19$ & $1.50 \pm 0.35$ & $72.82 \%$ & $<\mathbf{0 . 0 0 1}^{*}$ \\
\hline \multicolumn{7}{|c|}{ After crossover } \\
\hline $\begin{array}{l}\text { Plaque } \\
\text { index }\end{array}$ & $1.29 \pm 0.25$ & $0.59 \pm 0.20$ & $0.70 \pm 0.29$ & $54.26 \%$ & $<\mathbf{0 . 0 0 1 *}$ \\
\hline
\end{tabular}


Table no. 3: Intragroup comparison of Sulcus Bleeding Index in Herbal group before and after crossover

\begin{tabular}{|c|c|c|c|c|c|}
\hline & $\begin{array}{l}\text { Baseline } \\
\text { (mean is SD) }\end{array}$ & $\begin{array}{l}\text { Final } \\
\text { (mean it } \\
\text { SD) }\end{array}$ & $\begin{array}{l}\text { Mean } \\
\text { Change }\end{array}$ & $\begin{array}{l}\% \\
\text { reduction }\end{array}$ & $\begin{array}{l}\text { Pvalue } \\
\text { Paired } \\
\text { (est) }\end{array}$ \\
\hline \multicolumn{6}{|c|}{ Before crossover } \\
\hline $\begin{array}{l}\text { Sulcus } \\
\text { bleeding } \\
\text { index }\end{array}$ & $2.05 \pm 0.25$ & $0.71 \pm 0.16$ & $1.34 \neq 0.28$ & $65.37 \%$ & $-0.001^{*}$ \\
\hline \multicolumn{6}{|c|}{ After crossover } \\
\hline $\begin{array}{l}\text { Sulcus } \\
\text { bleeding } \\
\text { index }\end{array}$ & $1.43 \neq 0.23$ & $0.43=0.18$ & $1.00=0.24$ & $6993 \%$ & $<0.001^{*}$ \\
\hline
\end{tabular}

Table no. 4: Intragroup comparison of Sulcus Bleeding Index in Triclosan group before and after crossover

\begin{tabular}{|l|l|l|l|l|l|}
\hline & $\begin{array}{l}\text { Baseline } \\
\text { (mean } \pm \text { SD) }\end{array}$ & $\begin{array}{l}\text { Final } \\
\text { (mean } \pm \\
\text { SD) }\end{array}$ & $\begin{array}{l}\text { Mean } \\
\text { Change }\end{array}$ & $\begin{array}{l}\% \\
\text { reduction }\end{array}$ & $\begin{array}{l}\text { P value } \\
\text { (Paired t } \\
\text { test) }\end{array}$ \\
\hline \multicolumn{5}{|c|}{ Before crossover } \\
\hline $\begin{array}{l}\text { Sulcus } \\
\text { bleeding } \\
\text { index }\end{array}$ & $2.13 \pm 0.18$ & $0.47 \pm 0.19$ & $1.66 \pm 0.20$ & $77.93 \%$ & $<0.001^{\star}$ \\
\hline \multicolumn{5}{|c|}{ After crossover } \\
\hline $\begin{array}{l}\text { Sulcus } \\
\text { bleeding } \\
\text { index }\end{array}$ & $1.16 \pm 0.22$ & $0.57 \pm 0.17$ & $0.58 \pm 0.22$ & $50.00 \%$ & $<0.001^{\star}$ \\
\hline
\end{tabular}

Table no. 5: Intragroup comparison of Gingival Index in Herbal before and after crossover

\begin{tabular}{|l|l|l|l|l|l|}
\hline & $\begin{array}{l}\text { Baseline } \\
\text { (mean } \pm \text { SD) }\end{array}$ & $\begin{array}{l}\text { Final } \\
(\text { mean } \\
\text { SD) }\end{array}$ & $\begin{array}{l}\text { Mean } \\
\text { Change }\end{array}$ & $\begin{array}{l}\% \\
\text { reduction }\end{array}$ & $\begin{array}{l}\text { Pvalue } \\
\text { (Paired t } \\
\text { test) }\end{array}$ \\
\hline \multicolumn{6}{|c|}{ Before crossover } \\
\hline $\begin{array}{l}\text { Gingival } \\
\text { index }\end{array}$ & $2.18 \pm 0.26$ & $0.97 \pm 0.31$ & $1.21 \pm 0.27$ & $55.50 \%$ & $<\mathbf{0 . 0 0 1 ^ { * }}$ \\
\hline \multicolumn{6}{|c|}{ After crossover } \\
\hline $\begin{array}{l}\text { Gingival } \\
\text { index }\end{array}$ & $1.39 \pm 0.25$ & $0.44 \pm 0.15$ & $0.95 \pm 0.19$ & $68.35 \%$ & $<\mathbf{0 . 0 0 1 *}$ \\
\hline
\end{tabular}

Table no. 6: Intragroup comparison of Gingival Index in Triclosan group before and after crossover

\begin{tabular}{|c|c|c|c|c|c|}
\hline & $\begin{array}{l}\text { Baseline } \\
(\text { mean } \pm S D)\end{array}$ & $\begin{array}{l}\text { Final } \\
(\text { mean } \pm \text { SD })\end{array}$ & $\begin{array}{l}\text { Mean } \\
\text { Change }\end{array}$ & $\begin{array}{l}\% \\
\text { reduction }\end{array}$ & $\begin{array}{l}\text { Pvalue } \\
\text { Paired t } \\
\text { test) }\end{array}$ \\
\hline \multicolumn{6}{|c|}{ Before crossover } \\
\hline $\begin{array}{l}\text { Gingival } \\
\text { index }\end{array}$ & $2.06 \pm 0.23$ & $0.60 \pm 0.19$ & $1.46 \pm 0.30$ & $70.87 \%$ & $<0.001 *$ \\
\hline \multicolumn{6}{|c|}{ After crossover } \\
\hline $\begin{array}{l}\text { Gingival } \\
\text { index }\end{array}$ & $1.32 \pm 0.31$ & $0.60 \pm 0.21$ & $0.72 \pm 0.24$ & $54.55 \%$ & $<0.001 *$ \\
\hline
\end{tabular}




\section{Intergroup comparison}

Table no.7: Intergroup comparison of change in Plaque Index before and after crossover

\begin{tabular}{|l|l|l|l|}
\hline & Herbal group & Triclosan group & $\begin{array}{l}\text { P value } \\
\text { (Unpaired test) }\end{array}$ \\
\hline \multicolumn{5}{|c|}{ Before crossover } \\
\hline $\begin{array}{l}\text { Plaque index } \\
\text { mean } \pm \text { SD) }\end{array}$ & $1.19 \pm 0.25$ & $1.50 \pm 0.35$ & $<0.001^{*}$ \\
\hline \multicolumn{3}{|c|}{ After crossover } \\
\hline $\begin{array}{l}\text { Plaque index } \\
\text { (mean } \pm \text { SD) }\end{array}$ & $0.70 \pm 0.29$ & $0.98 \pm 0.28$ & $<0.001^{\star}$ \\
\hline
\end{tabular}

Table no.8: Intergroup comparison of change in Sulcus Bleeding Index before and after crossover

\begin{tabular}{|l|l|l|l|}
\hline & Herbal group & Triclosan group & $\begin{array}{l}\text { P value } \\
\text { (Unpaired t test) }\end{array}$ \\
\hline \multicolumn{4}{|c|}{ Before crossover } \\
\hline $\begin{array}{l}\text { Sulcus bleeding } \\
\text { index } \\
\text { (mean } \pm \text { SD) }\end{array}$ & $1.34 \pm 0.28$ & $1.66 \pm 0.20$ & $<0.00 \star^{\star}$ \\
\hline \multicolumn{3}{|c|}{ After crossover } \\
\hline $\begin{array}{l}\text { Sulcus bleeding } \\
\text { index } \\
\text { (mean } \pm \text { SD) }\end{array}$
\end{tabular}

Table no.9: Intergroup comparison of change in Gingival Index before and after crossover

\begin{tabular}{|l|l|l|l|}
\hline & Herbal group & Triclosan group & $\begin{array}{l}\text { P value } \\
\text { (Unpaired t test) }\end{array}$ \\
\hline \multicolumn{4}{|c|}{ Before crossover } \\
\hline $\begin{array}{l}\text { Gingival index } \\
\text { mean } \pm \text { SD) }\end{array}$ & $1.21 \pm 0.27$ & $1.46 \pm 0.30$ & $\mathbf{0 . 0 0 2 ^ { \star }}$ \\
\hline \multicolumn{4}{|c|}{ After crossover } \\
\hline $\begin{array}{l}\text { Gingival index } \\
\text { (mean } \pm \text { SD) }\end{array}$ & $0.72 \pm 0.24$ & $0.95 \pm 0.19$ & $\approx 0.001^{\star}$ \\
\hline
\end{tabular}

\section{Discussion}

Dental plaque is a primary etiological factor in the initiation and progress of periodontal disease. Recent studies have demonstrated that microorganisms involved in the etiology of gingivitis and periodontitis accumulate on several soft tissue surfaces of the mouth, which serve as a nidus of bacteria for the colonization of tooth surfaces and soft tissues of the oral cavity ${ }^{24}$. Chemical anti-plaque agents present in mouthrinses or dentifrices can reach these soft tissue surfaces, improving the control of biofilm growth on these surfaces and delaying microbial accumulation on teeth ${ }^{25}$. Chronic gingival inflammation aggravates the tissue destruction, and if left untreated, may progress into the more destructive stages of periodontitis ${ }^{26}$.

The present study was conducted to compare and evaluate the dentifrice containing triclosan/polymer containing PVM/MA and dentifrice containing herbal extracts in its ability to control plaque and gingival inflammation. In the present study, the use of triclosan/ PVM/MA copolymer dentifrice showed considerable reduction( $\mathbf{p} \square \mathbf{0 . 0 5}$ ) in plaque accumulation and gingival inflammation (intragroup comparison). Plaque index scores showed percentage reduction of $72.82 \% \& 54.26 \%$ before and after crossover respectively. The reduction 
in PI scores may be attributed to the antimicrobial activity of triclosan/copolymer. Gingival index scores showed percentage reduction $(70.87 \%$ and $54.55 \%)$ before and after crossover while Sulcus Bleeding index showed percentage reduction $(77.93 \%$ and $50 \%$ ) before and after the crossover possibly attributed to the antiinflammatory properties of triclosan as a result of inhibition of cyclooxygenase/ lipoxygenase pathways ${ }^{27}$. This is supported by Rover $\mathbf{J}(2014)^{28}$ who confirmed the findings that triclosan/copolymer was effective in reducing plaque and gingivitis.

The present study also showed reduction in plaque accumulation and gingival inflammation $(\mathrm{p} \leq 0.05)$ with the herbal dentifrice (intragroup comparison). PI scores showed percentage reduction of 58.05\% and $67.59 \%$ before and after the crossover. Gingival index scores showed percentage reduction $(55.50 \%$ and $68.35 \%)$ before and after crossover while Sulcus Bleeding index showed percentage reduction $(65.37 \%$ and $69.93 \%$ ) before and after the crossover. This findings may be attributed to antimicrobial activity resulting from the presence of secondary metabolites such alkaloids, flavonoids, polyphenols and lectins and anti-inflammatory action of herbal extracts. These findings are supported by George $\mathbf{J}$ et al $(2009)^{29}$ who established in a double blinded controlled clinical trial that the herbal-based toothpaste was as effective as the conventionally formulated triclosan containing dentifrice in the control of plaque and gingivitis.

These findings are similar to Tatikonda A et al $(2014)^{30}$ who found that clinically, herbal dentifrices were as effective as triclosan (conventional) dentifrices in the control of plaque and gingivitis and showed statistical significance in intra group comparison $(\mathrm{p}<0.05)$. Additionally, these findings are in correspondence with Amrutesh S et al $(2010)^{31}$ who showed that herbal dental cream was as safe and effective as triclosan \& fluoride containing dental cream in the treatment of gingivitis and the control of plaque.

However the intergroup comparison revealed statistically significant $(p \leq 0.05)$ reduction in Plaque Index, Sulcus Bleeding Index scores in Group B (Triclosan/copolymer) as compared to Group A (Herbal group) before and after crossover. This might be attributed to the superior antimicrobial activity of triclosan which acts by inhibiting the enzyme enoyl-acyl carrier protein reductase (ENR) thereby blocking lipid biosynthesis and anti-inflammatory action ${ }^{32}$. However the Gingival Index scores,although statistically significant after the crossover in favour of Group B, did not show any significant difference before the crossover in Group B (Triclosan/copolymer) as compared to Group A(Herbal group). This may be attributed to the patient compliance and additionally to the inter-individual variation in reduction of inflammation despite reduction in plaque scores.

The results of the present study were in accordance with the work done by Deshpande R $(2014)^{33}$ who found that fluoridated triclosan toothpaste had maximum antimicrobial activity at all concentrations when compared to herbal toothpaste which was statistically significant $(\mathrm{p}<0.05)$ As compared to them, the present study evaluated the efficacy of the dentifrices using clinical indices of gingival inflammation as opposed to salivary sample assessment of antimicrobial efficacy. The results of the study are in accordance with Nwankwo IU \& Ihesiulo SC(2014) ${ }^{34}$ who concluded that triclosan containing toothpaste formulation was more effective in the control of oral microflora (E. coli, S. aureus, Streptococcus spp) compared to non triclosan and herbal toothpaste formulations. This finding might be due to the superior antimicrobial property of triclosan. Results of the present study are similar to the study conducted by Ledder R et al $(2014)^{35}$ who showed that the triclosancontaining formulation caused greater bacterial viability reductions $(\mathrm{p}<0.05)$ than the herbal and non herbal formulations. They assessed the results of the study on the basis of the viability staining and profiling whereas the present study assessed the clinical parameters of gingival inflammation.

Likewise results of this study concur with Prasanth M $(2011)^{36}$ who deduced that triclosan containing toothpastes formulations were more effective $(\mathrm{p}<0.05)$ in control of oral microflora $(\mathrm{E}$. coli, S. mutans, C. albicans) compared to non-triclosan and herbal toothpastes. This could be possibly explained by antiinflammatory and antimicrobial action of triclosan.

The results of the present study is in contrast with that of De Rossi A et al (2014) ${ }^{37}$ who conducted an in vitro study to evaluate the antimicrobial effect of toothpastes containing natural extracts, $0.12 \%$ chlorhexidine, $0.3 \%$ triclosan and conventional toothpaste (control) and found that all formulations, except for conventional toothpaste showed antimicrobial activity against Gram-positive bacteria and yeasts $(p>0.05)$ whereas the toothpaste containing natural extracts was the only product that was able to inhibit the growth of Gram-negative bacteria (Pseudomonas aeruginosa). The difference might be explained by the different herbal components which demonstrated antiseptic,anti-inflammatory and antimicrobial propertiesas well as the synergistic interaction of the principal components of the herbs contributing to their antimicrobial property.

Similarly a study was conducted by Gupta $\mathrm{P}(2012)^{38}$ comparing the efficacy of commercially available over the counter herbal dentifrices in comparison with triclosan containing conventional dentifrice(Colgate Total) on Streptococcus sanguis and found that amongst 9 herbal dentifrices, Miswak (Salvadora persica) \& Promise (Clove oil) showed better results as compared to triclosan containing dentifrice. These results are not consistent with the present study. The authors estimated the antimicrobial action by measuring the Maximum Zone of Inhibition as opposed to the present study wherein the clinical parameters of gingival inflammation 
were considered. The difference between the results can possibly be attributed to the fact that a dentifrice used in vivo is likely to be diluted by saliva resulting in buffering or dilution of the antimicrobial properties and thereby the effect which is unaccounted for in this study as it is an in vitro study.

The results of present study is not in accordance with the study conducted by Tangade $\mathrm{P}$ et al $(2012)^{39}$ who found reductions in PI, GI and BOP\% in the Acacia arabica containing toothpaste (test group) $(\mathrm{p}<0.05)$ compared with the triclosan containing toothpaste (control group). The authors of the above study have specifically chosen individuals from the low socioeconomic group and also have not modified any of their oral hygiene habits whereas in the present study individuals from all socioeconomic strata were chosen and motivated to modify their oral hygiene habits which might have had a bearing on the results obtained.

Gupta $\mathrm{P}(2012)^{40}$ found that there were significant differences $(\mathrm{p}<0.05)$ in the reduction of plaque by the herbal dentifrice, Meswak (Salvadora persica) in comparison with triclosan. These results are in contrast to the present study. This difference might be attributed to the difference in the study design. This study is a parallel design while the present study is a crossover.

\section{The Following Points Can Be Considered As The Limitations Of The Study:}

- Longitudinal studies of a longer study duration should be carried out to evaluate these agents using a larger sample size.

- Since there are multiple ingredients in the herbal dentifrice, individual action of these ingredients are not known clearly and therefore need to be investigated.

- Lack of standardization in selection of subjects from various socioeconomic groups might have a bearing on the final results.

\section{Conclusion}

In the present study, Triclosan is shown to be more effective in plaque control and resolution of gingival inflammation as compared to the herbal extracts. The data however suggested that both the products had anti-inflammatory and antimicrobial properties. Considering the excellent antimicrobial and antiinflammatory and the proven worth of both these agents it might be worth a shot to investigate the role of both these agents in combination with each other. Also these agents can also be made available in other forms eg:mouthrinses, chewable tablets and their efficacy researched. To conclude long term follow-up studies are required to assess the efficacy of the treatment procedures

\section{Acknowledgements}

I would like to thank Colgate Palmolive Ltd and Himalaya Drug Company for the immense support and encouragement and also for providing the necessary samples required in the course of the study.

\section{References}

[1]. Ash M, Gitlin BN, Smith NA. Correlation between plaque and gingivitis. J Periodontol. 1964; 35:425-429.

[2]. Lindhe J. Gingivitis General discussion. J ClinPeriodontol. 1986; 13:395.

[3]. Löe H. Progression of natural untreated periodontal disease in man. In: Lehner T, Cimasoni G. The borderland between caries and periodontal disease III. Geneve: Editions Medecinet Hygiene 1986: pp 11-29.

[4]. Dahlén G, Lindhe J, Sato K, Hanamura H, Okamoto H. The effect of supragingival plaque on the subgingivalmicrobiota in subjects with periodontal disease. J ClinPeriodontol. 1992; 19:802-809.

[5]. Haffajee AD, Smith C, Torresyap G, Thompson M, Guerrero D, Socransky SS. Efficacy of manual and powered toothbrushes (II).Effect on microbiological parameters. J ClinPeriodontol. 2001; 28:947-954.

[6]. Eley BM. Antibacterial agents in the control of supragingival plaque- a review. British Dental Journal. 1999; 186:286-296.

[7]. Gaffar A, Volpe A, Lindhe J. Recent advances in plaque/gingivitis control. In: Embery G \& Rolla C. Clinical and Biological Aspects of Dentifrices. Oxford: Oxford University Press 1992: 229-248.

[8]. Arun N, Singh DP. Punicagranatum: A review on pharmacological and therapeutic properties. Int J Pharm Sci Res. 2012; 3:1240-5.

[9]. Brijwal L, PandeyA ,Tamta S. An overview on phytomedicinal approaches of ZanthoxylumarmatumDC: An important magical medicinal plant. Journal of Medicinal Plants Research. 2013; 7(8):366-370.

[10]. Rajvaidhya S, NagoriBP , Singh GK, Dubey BK, Desai P, Jain S. A review on Acacia arabica- An Indian medicinal plant.Int J Pharm Sci Res. 2012; 3(7): 1995-2005.

[11]. Jagtap AG \&Karkera SG. Potential of the aqueous extract of Terminaliachebula as an anticaries agent. J Ethnopharmacol. 1999; 68(1- 3), 299-306

[12]. Date BB \&Kulkarni PH. Assessment of Rasadanti in various oral disorders. Ayurveda Res. 1995; Pap. 2: $197-175$.

[13]. Sabu MC, Kuttan R. Antidiabetic activity of medicinal plants and its relationship with their antioxidant property. J Ethanopharmacol. 2002; 81,155-160.

[14]. Souravi K, Rajasekharan PE. A Review on the Pharmacology of EmbeliaribesBurm.F.- A threatened medicinal plant.Int J Pharm Bio Sci. 2014; 5(2) : 443 - 456.

[15]. Tandon V. Medicinal uses and biological activities of VitexNegundo. Natural product radiance. 2005; 4(3): 162-165.

[16]. Dutta S, Shaikh A. The Active Chemical Constituent And Biological Activity of Salvadora persica (Miswak). International Journal of Current Pharmaceutical Review and Research. 2012; 3(1): 1-14.

[17]. Hukkeri VI, Savadi RV, Tippimath CD, Karadi RV, Jaiprakash B. Anti-inflammatory activity of leaves of Acacia farnesianaWilld. Indian drugs. 2002; 39(12):664-666. 
[18]. Hashmat M, Hussain R. A review on Acacia catechu Willd. Interdisciplinary Journal of Contemporary Research in Business. 2013; 5(1):593-600.

[19]. Kadam P, Yadav K, Deoda R, Shivatare R, Joshi M. Mimusopselengi: A review on Ethnobotany, Phytochemical and Pharmacological Profile. J PharmacognPhytochem. 2012; 1(3):64-74.

[20]. Javed S, Shahid AA, Haider MS, Umeera A, Ahmad R, Mushtaq S. Nutritional, phytochemical potential and pharmacological evaluation of Nigella Sativa (Kalonji) and TrachyspermumAmmi (Ajwain). J Med Plants Res. 2012; 6(5):768-775.

[21]. Biswas K, Chattopadhyay I, Banerjee R, Bandyopadhyay. Biological activities and medicinal properties of neem (Azadirachtaindica). Current Science. 2002; 82(11):1336-1345.

[22]. Loe H. The Gingival Index, the Plaque Index and the Retention Index Systems. J Periodontol.1967; 38(6):610-16.

[23]. Muhlemann HR, Son S. Gingival sulcus bleeding-a leading symptom in initial gingivitis. HelvOdontol Acta.1971; 15(2):107-13.

[24]. Socransky SS, Haffajee AD. Periodontal microbial ecology. Periodontol 2000. 2005; 38:135-87.

[25]. Sekino S, Ramberg P, Uzel NG, Socransky S, Lindhe J. The effect of a chlorhexidine regimen on de novo plaque formation. J ClinPeriodontol. 2004; 31(8):609-14.

[26]. Mariotti A. A primer on inflammation. CompendContinEduc Dent. 2004; 25:7-15.

[27]. Gaffar A, Scherl D, Afflitto J, Coleman E J. The effect of triclosan on mediators of gingival inflammation. J ClinPeriodontol. 1995; 22: 480-484.

[28]. Rover J ,Leu-Wai-See P. Role of Colgate Total toothpaste in helping control plaque and gingivitis. Am Dent J. 2014; 27:167-170.

[29]. George J, Hegde S, Rajesh KS, Kumar A. The efficacy of a herbal-based toothpaste in the control of plaque and gingivitis: a clinico-biochemical study.Indian J Dent Res. 2009; 20(4):480-482.

[30]. Tatikonda A, Debnath S, Chauhan V, Chaurasia V, Taranath M, Sharma A. Effects of herbal and non-herbal toothpastes on plaque and gingivitis: A clinical comparative study. J IntSocPrev Community Dent. 2014; 4:126-129.

[31]. Amrutesh S, Malini J, Tandur P, Patki P. Clinical evaluation of a novel herbal dental cream in plaque formation: a double blind, randomized, controlled clinical trial. J ExpPharmacol. 2010; 2:105-109.

[32]. McMurry LM, Oethinger M, Levy SB. Triclosan targets lipid synthesis. Nature. 1998; 394(6693):531-2.

[33]. Deshpande R, Kachare P, Sharangapani G, Varghese V, Bahulkar S. Int J Pharm Pharm Sci. 2014; 6(2):72-74.

[34]. Nwankwo IU\&Ihesiulo SC. Comparative Analysis of the Antibacterial Potentials of Some Brands of Toothpaste Commonly Used In UmuahiaAbia State. Journal of Pharmacy and Biological Sciences.2014 ; 9:50-54.

[35]. Ledder R, Latimer J, Humphreys G, Sreenivasan P, McBain A.Bacteriological Effects of Dentifrices with and without Active Ingredients of Natural Origin. Appl. Environ. Microbiol.2014; 80:6490-6498.

[36]. Prasanth M. Antimicrobial Efficacy of Different Toothpastes and Mouthrinses: An In Vitro Study. Dent Res J. 2011; 8(2): 85-94

[37]. De Rossi A, Ferreira D, Da Silva R, De Queiroz A, Da Silva L, Filho P. Antimicrobial Activity of Toothpastes Containing Natural Extracts, Chlorhexidine or Triclosan. Braz Dent J. 2014; 25: 186-190.

[38]. Gupta P, Agrawal N, Sharma R. Evaluating the anti plaque efficacy of herbal dentifrices - An invitro study.Int J A P S BMS. 2012; 1 (2):150-159.

[39]. Tangade P, Mathur A, Tirth A, Kabasi S. Anti-gingivitis Effects of Acacia arabica containing toothpaste. Chin J Dent Res. 2012; $15(1)$.

[40]. Gupta P, Agarwal N, Anup N, ManujunathBC , Bhalla A. Evaluating the anti- plaque efficacy of meswak (Salvadorapersica) containing dentifrice: A triple blind controlled trial. J Pharm Bioallied Sci. 2012; 4(4): 282-285. 